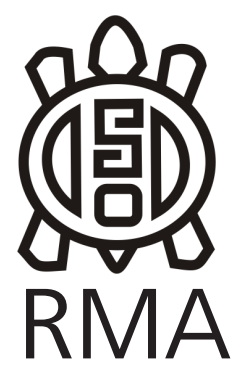

Homenaje a

José Antonio Pérez Gollán

\section{JOSÉ ANTONIO PÉREZ GOLLÁN}

1937-2014

In memoriam
José Antonio Pérez Gollán, o Pepe Pérez a secas, nació en Córdoba el 8 de Diciembre de 1937. Académicamente se formó en la Universidad Nacional de Córdoba alcanzando su título de grado como Licenciado en Historia y Doctor en Historia en la Facultad de Filosofía y Humanidades. Sin duda su paso por este ámbito forjó mucho de lo que luego iba a implementar en su práctica profesional tanto en nuestro país como en México, nación que lo recibió en su exilio durante la dictadura cívico-militar (1976-1983).
Los conocimientos de la arqueología de Córdoba y del NOA han dejado su huella en esta Universidad, particularmente a través de un proyecto de arqueología comenzado en la década de 1970 (que había quedado trunco por su partida al exterior) y que fuera retomado y apoyado desde el Museo de Antropología. Este proyecto desarrollado en el Valle de Ambato, en la Provincia de Catamarca, permitió su vuelta al trabajo de campo y fue sin duda un hito en la comprensión de diversos aspectos

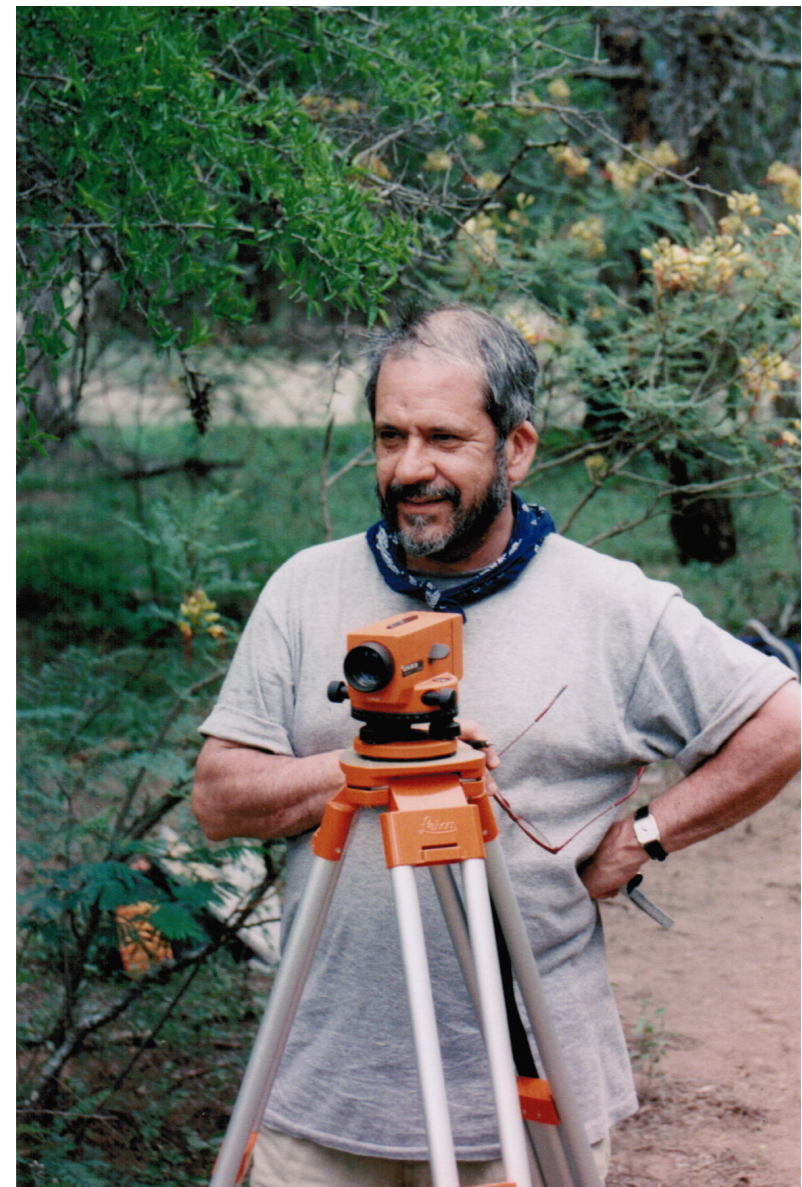

Pepe Pérez realizando un relevamiento plani-altimétrico en Terrazas del Cerco, Ambato, Catamarca, Abril de 1995 (Foto Colección Laguens-Bonnin, Reserva Patrimonial, Museo de Antropología-IDACOR, Digitalizado en el marco del Proyecto de Informatización y Digitalización de las Colecciones y Archivo del Museo de Antropología-IDACOR) 
de la vida de las sociedades prehispánicas que ocuparon la región en los últimos 2000 años. Su interés en la religión, los contactos a larga distancia y los aspectos más simbólicos de estas sociedades son sin dudas uno de los legados más importantes para nuestra institución. Tanto es así que uno de sus trabajos (El jaguar en llamas. La religión en el antiguo Noroeste argentino) fue uno de los textos obligatorios con los que se abrió la carrera de Antropología creada en el año 2010.

Por otro lado su faceta de gestor y director de museo tuvo un gran impacto en el tipo de museología que se viene implementado en el Museo de AntropologíaIDACOR, donde la conservación preventiva, la nueva museografía, la educación, entre otros aspectos han ido desarrollándose hasta alcanzar un nivel de excelencia internacional.

Si bien sus últimos años fueron vividos en la ciudad de Buenos Aires, sus viajes frecuentes a Córdoba y su trabajo con investigadores locales han dejado una impronta que no se borrará fácilmente y que sin duda seguirá guiando a los nuevos profesionales que se encuentran formando en nuestro universidad.

Lamentamos su pérdida física ocurrida el 24 de mayo del corriente año, pero sabemos que su legado académico y su enseñanzas perdurarán en la memoria y la práctica de quienes supimos conocerlo. 